Meta

Journal des traducteurs

Translators' Journal

\title{
Foreign Is Not Unfamiliar. A Translation Impact Study Involving Taiwan Subjects
}

\section{Qianting Wang, Hui-Wen Chen et Yong Zhong}

Volume 54, numéro 2, juin 2009

URI : https://id.erudit.org/iderudit/037685ar

DOI : https://doi.org/10.7202/037685ar

Aller au sommaire du numéro

Éditeur(s)

Les Presses de l'Université de Montréal

ISSN

0026-0452 (imprimé)

1492-1421 (numérique)

Découvrir la revue

Citer cette note

Wang, Q., Chen, H.-W. \& Zhong, Y. (2009). Foreign Is Not Unfamiliar. A Translation Impact Study Involving Taiwan Subjects. Meta, 54(2), 342-356. https://doi.org/10.7202/037685ar
Résumé de l'article

Le présent article fait état des travaux issus du troisième volet d'une recherche portant sur les effets de traductions " étrangéisées » ou naturalisées, qui ont été observés chez un échantillon de lecteurs. Les deux premiers volets de cette recherche avaient été menés dans deux villes de Chine continentale (Beijing et Guangzhou), tandis que le troisième volet a été réalisé à Douliou, à Taiwan. Il est ainsi possible de comparer les résultats à ceux qui ont été obtenus antérieurement. L'article introduit brièvement le contexte du projet mené à Taiwan ainsi qu'un bref profil des sujets participants. Le plan de l'étude est ensuite présenté, y compris les hypothèses et la méthodologie de collecte des données. Quatre hypothèses ont été testées : a) les sujets distinguent clairement les deux modes de traduction ; b) ils éprouvent davantage un sentiment d'exotisme à la lecture de la version étrangéisée ; c) leur opinion quant au caractère exotique ou non de la traduction est corrélée aux autres caractéristiques sociolinguistiques perçues pour le texte; d) les résultats de la présente étude corroborent ceux qui ont été obtenus dans le cadre des deux premiers volets. La description du plan de l'étude est suivie de la présentation de l'analyse des données, laquelle est accompagnée des conventions nécessaires à l'interprétation des calculs statistiques. L'interprétation des résultats au regard des hypothèses avancées se fonde sur cette analyse.
Ce document est protégé par la loi sur le droit d'auteur. L’utilisation des services d'Érudit (y compris la reproduction) est assujettie à sa politique d'utilisation que vous pouvez consulter en ligne.

https://apropos.erudit.org/fr/usagers/politique-dutilisation/ 


\title{
Foreign Is Not Unfamiliar. A Translation Impact Study Involving Taiwan Subjects
}

\author{
QIANTING WANG \\ China Radio International, Beijing, China \\ kate.wong@163.com \\ HUI-WEN CHEN \\ Chang Jung Christian University, Tainan, Taiwan \\ krischen@mail.cjcu.edu.tw \\ YONG ZHONG \\ University of New South Wales, Sydney, Australia \\ y.zhong@unsw.edu.au
}

\section{RÉSUMÉ}

Le présent article fait état des travaux issus du troisième volet d'une recherche portant sur les effets de traductions «étrangéisées » ou naturalisées, qui ont été observés chez un échantillon de lecteurs. Les deux premiers volets de cette recherche avaient été menés dans deux villes de Chine continentale (Beijing et Guangzhou), tandis que le troisième volet a été réalisé à Douliou, à Taiwan. Il est ainsi possible de comparer les résultats à ceux qui ont été obtenus antérieurement. L'article introduit brièvement le contexte du projet mené à Taiwan ainsi qu'un bref profil des sujets participants. Le plan de l'étude est ensuite présenté, y compris les hypothèses et la méthodologie de collecte des données. Quatre hypothèses ont été testées: a) les sujets distinguent clairement les deux modes de traduction; b) ils éprouvent davantage un sentiment d'exotisme à la lecture de la version étrangéisée; c) leur opinion quant au caractère exotique ou non de la traduction est corrélée aux autres caractéristiques sociolinguistiques perçues pour le texte; d) les résultats de la présente étude corroborent ceux qui ont été obtenus dans le cadre des deux premiers volets. La description du plan de l'étude est suivie de la présentation de l'analyse des données, laquelle est accompagnée des conventions nécessaires à l'interprétation des calculs statistiques. L'interprétation des résultats au regard des hypothèses avancées se fonde sur cette analyse.

\begin{abstract}
The research discussed in this paper is the last of a trilogy investigating the impact of foreignized and domesticated translations on sampled readers. The two precursors had been conducted in two Chinese Mainland cities (Beijing and Guangzhou) and this last one was conducted in the Taiwanese city of Douliou. Therefore, comparisons can be made with the two precursors in the discussion of the research procedure and findings of the Taiwan project. The paper begins with a brief introduction of the background in which the Taiwan project was conceived and a brief profile of the subjects sampled for the project. Then there is a description of the research design, including the hypotheses and field work methodology. Four hypotheses were tested: a) the subjects would have distinguishable ideas about the two renditions; b) they would have a more intense feeling of exoticism when reading the foreignized rendition; c) their degree of sensing the rendition to be
\end{abstract}


exotic or not would be correlated with their other socio-linguistic perceptions of that text; d) the findings of the present investigation would corroborate those obtained from the two precursors. The description of the research design is followed by a presentation of the data analysis conducted for the project together with a statement of the conventions adopted for reading the statistics. Based on the data analysis, interpretations are made in relation to the hypotheses.

\section{MOTS-CLÉS/KEYWORDS}

étrangéisation, naturalisation, étranger familier, études sur les conséquences de la traduction, Taiwan

foreignization, domestication, the foreign familiar, translation impact studies, Taiwan

\section{Introduction}

In this paper, we will discuss a research project, which was designed to investigate the impact of foreignized and domesticated translations on a sample of Chinese language readers in the Taiwanese city of Douliou. "Foreignization" and "domestication" are two concepts with a history in translation and translation studies. They began with Schleiermacher's discussion of alienation and naturalization in the early $19^{\text {th }}$ century [as seen in a recent republication (Schleiermacher 1813/1992)], which referred to two opposing strategies of either moving the author towards the reader or the other way round. They then appeared directly or indirectly in Benjamin's (1963) and Berman's (1985) discussions of translation strategies and philosophies. In recent postcolonial writings, Venuti (1995) politicized the concepts in a postcolonial context where domestication ethnocentrically reduced the foreign text to the target language cultural values whereas foreignization ethnodeviantly pressured the target language culture to register the linguistic and cultural difference of the foreign text. In short, "foreignization" and "domestication" were often contrasted to each other and were given great attention in translation studies.

But there was limited scientifically generated knowledge about what impact foreignized and domesticated renditions would actually have on readers of translation and whether they would actually create distinguishable impacts. So Zhong and his associates undertook two projects involving subjects in the two Mainland Chinese cities of Beijing and Guangzhou ${ }^{1}$. They studied whether the two renditions of the same source text (ST), which were to be used in the present investigation and had been constructed on the basis of the two academically significant concepts of foreignization and domestication, were distinguishable from the sampled subjects and whether perceptions about either rendition followed a predictable pattern. Intended as a sequel, the present project adopted the core research design and methodology of the precursors but involved subjects sampled in Taiwan, i.e., people who spoke a similar language but lived in a socio-linguistically very different environment.

The two precursors found that the two renditions were more likely to impact indistinguishably than significantly distinguishably, that the foreign rendition prompted a greater feeling of exoticism in the Guangzhou sample but not in the Beijing one, that neither rendition was seen as cognitively more inaccessible or sociolinguistically superior even if it appeared to be exotic. There were a few instances where one rendition was found to have a significantly greater impact than the other, or have a significant to moderate correlation with certain sociolinguistics ideas. But 
these situations were few in number and unpredictable in distribution. There was one exception, which the analysed data of the two precursors could not explain - subjects in both samples found the writer of the foreignized rendition to be more imaginative than that of the domesticated.

Thinking that foreignization and domestication were such important academic concepts, the researchers of the precursors had expected that the two renditions would readily be seen as distinct, would impact distinguishably and would arouse certain predictably correlated sociolinguistic perceptions. So the rather consistent findings of the Beijing and Guangzhou projects surprised us. Why were the two presumably different renditions not generally seen as different? Why was it that a foreignized or a foreign-looking text was not seen as cognitively more inaccessible? Why was it that there were few correlations between an exotic idea and other sociolinguistic ideas? Were the findings reliable with regard to the relatively small size of samples? To tackle these questions, we decided to conduct the study yet again, but this time in a Taiwanese locale.

\section{The Taiwan project and subjects sampled}

The Taiwan project was not intended to be just another testing ground to test the same hypotheses as in the precursors. It did occur to us that involving a larger population of subjects sampled from different locations would increase the reliability of our research. It would also be interesting to compare the findings of projects conducted in Mainland China and Taiwan, two Chinese-speaking environments, which were under different political and social jurisdictions. Furthermore, Professor Chen, one of the co-authors of this paper, was able to provide valuable administrative and logistical support for this project. But it was another consideration which more than anything else influenced the inclusion of the Taiwan project.

We had thought that language as a rather intangible construct was constantly evolving and, particularly in Mainland China, Mandarin was subject to even more drastic changes due to the numerous political movements since the communists took it over from the nationalists who fled to Taiwan in 1949. The many movements included notably the Anti-Rightists Movement in the late 1950's, the Great Cultural Revolution from 1967 to 1976 and the Reform Movement starting in the 1980's. Mandarin (known as Putonghua in Mainland China) forcibly became the language of governing, social activities, education, business and almost everything else. Traditional literature and books, together with much of the traditional expressions, were banned. Characters used to write in Mandarin were simplified. Foreign language and foreign language books were banned during some of these movements and artificially promoted during others, causing and reflecting the rapid fluctuations in language attitudes and perceptions. This, we believed, was a sign of the complexity in language attitude and perceptions in Mainland China.

By comparison, Taiwan was consistently more respectful of the traditional Chinese heritage and we are aware of no major politically engineered movements intended to change the Mandarin language. That is, except that the Kuomingtang (i.e., the nationalists who fled to Taiwan after losing the Mainland to the Communists) promoted Mandarin as the official language in the second half of the $20^{\text {th }}$ century as it tried to limit the use of the Taiwanese, the language of the Island comprising ele- 
ments of Ho-lo, Hakka and other aboriginal vernaculars. Recently, the government of Taiwan, formed by the democratically elected Democratic Progressive Party, campaigned to restore Taiwanese as the "mother tongue" of the Island. But all things considered, the evolution of Mandarin in Taiwan seems to have followed a more natural course. This other consideration - the lure of a more stable linguistic testing ground - motivated our decision to repeat the project in the Taiwanese city of Douliou.

The subjects sampled for this project provide a sociolinguistic snapshot of university students at Douliou. They were all enrolled students in the Department of Applied Foreign Languages of the Yunlin University of Science and Technology (often known as YunTech University), where Chen was a staff member at the time of the project. They included 14 students from a year-two class, 22 students from a yearthree class and 36 students from a year-four class. We decided to go for the homogeneous sample mainly because we were under-funded and two of the researchers were based outside Taiwan so there were inadequate resources for administering a genuine random-sampled project. Another reason was that the Beijing precursor had had a homogeneous sample too and so the findings of the two projects could be compared on a like-for-like basis.

The subjects were aged mostly between 20 and 24 (i.e., one to three years older than the Beijing subjects on average). All of them were native residents of Taiwan. Most of them lived in Douliou regularly and fewer than 20\% of them came from other parts of Taiwan. All of them spoke Chinese but more than $60 \%$ of them spoke Taiwanese as the first language at home or with friends or colleagues. Their Chinese proficiency was quite comparable to the Mandarin spoken by the Beijing subjects in terms of enunciation, grammar and writing. They tended to use different jargons and terminologies and seemed to be less versed in Chinese rhetoric (including use of idioms) but had no difficulty reading Chinese language literature in general and the two cues in particular. They usually wrote in full characters but they could, with some effort, also understand the simplified system of writing used in Mainland China. (To avoid unnecessary interference in this project, the cues to be inspected by the Taiwan subjects were prepared in full characters.) They appeared to be as well read in classical Chinese literature as their Beijing counterparts.

With regard to reception of foreign information, the Taiwan subjects seemed to have somewhat more open exposure to foreign cultural artefacts, especially books, movies, literature and media content than the Beijing subjects. They also appeared open to a greater diversity of foreign literature, including both serious and popular literature from Anglo-Saxon, Franco, Japanese, Spanish and Latin American sources. This was perhaps due to their living in a more open society which had more respect for personal choices and aspirations and more opportunities for educational and social advancement. Furthermore, the Taiwan subjects seemed particularly susceptible to the influences of Japanese culture and literature.

\section{Research design and procedure}

Zhong designed this Taiwan project on the basis of the Beijing and Guangzhou projects. The hypotheses, the interview procedures, and questionnaires and the statistical analysis were all very similar so that the results of this project could be compared 
with the findings of the two precursors. Chen, herself a faculty member at the YunTech University where the survey was conducted, prospected, sampled and profiled the subjects and undertook the survey. Zhong and Chen conducted an in-depth interview with six of the sampled subjects using a semi open-ended questionnaire. Wang helped to enter and statistically process the survey data which was discussed and interpreted by the three authors as the basis for this paper. We will now discuss the research deign and procedure beginning with the basic procedures used for the project.

\subsection{Research procedure}

The research procedure, adapted from the Beijing and Guangzhou projects, involved surveying the sampled subjects who received two renditions of the ST for examination. The two renditions, each known as a cue in the procedure, had been pre-constructed on the belief that one of them was typically foreignized and the other was typically domesticated. The subjects examining the two renditions were required to respond to a list of ten pre-set statements about each of the two renditions by ticking one of the pre-determined five rankings to indicate the degree to which they agreed or disagreed with each statement. Then the responses were statistically analysed and interpreted to test the preconceived hypotheses and to generate knowledge about the readers' perceptions. In the survey, the subjects were told that they were to evaluate two "texts." No explanation whatsoever was given as to the origin, author, quality and type of the texts. The interviewers expressly avoided confirming that the two texts were translations of any sort.

This procedure could be compared to the matched guise designed and used by Lambert and his associates to study language attitudes in Montreal in the 1960's (Lambert 1967). The matched guise had only one variable, ${ }^{2}$ i.e., that of either English or French vernacular whereas our procedure seemingly contained two variables, that of the rendition and that of the translator. Yet, we believed that the latter variable of our project was visible to the readers only through the former variable (remember Venuti's "invisibility" of the translator?), as a result of which we hoped the latter would be adequately merged and submerged by the former. We anticipated that our research procedure could also reveal what Lambert referred to as the subjects' "higher degree of introspection" about and "more private reactions" to two contrasting items.

\subsection{The hypotheses}

The main hypotheses are the following:

1. That Cue Foreign and Cue Domestic would prompt different responses.

2. That Cue Foreign would give the readers a greater feeling of being in a foreign environment when reading it.

3. That whether a cue prompts a feeling of being in a foreign environment would be correlated to other sociolinguistic perceptions about the cue.

As we intended to verify the findings of the Beijing and Guangzhou projects, there was implicitly a fourth hypothesis, namely:

4. That the findings of the Taiwan project would corroborate the findings of the two precursors. 


\subsection{The two cues}

The cues, i.e., the two renditions, were cited by Wen and Gao (2003) as typical examples of foreignization and domestication in a project funded by State Social Sciences Foundation, which is the central research funding council of the People's Republic of China (Project Serial No. 01BYY030). Wen and Gao had extracted them from published translations of the same book Gone With The Wind, authored by Margaret Mitchell and published in 1936. The one from which the foreignized rendition had been extracted was translated by Huairen Huang and Youruo Zhu and shall be known as "Cue Foreign" in this paper. The other one from which the domesticated rendition had been extracted was translated by Donghua Fu and shall be known as "Cue Domestic" hereafter. Zhong and his associate discussed a range of attributes that had been used to classify the two extracts as foreignized or domesticated in the Beijing paper. We will not repeat their discussions other than to reprint the original source text and the two Chinese extracts in the appendix.

\subsection{The questionnaire used for testing the hypotheses}

This project adopted the questionnaire used in the Beijing and Guangzhou projects, but in a full character format. The questionnaire consisted of 10 pairs of identical statements describing an attitude to or a judgment about the two renditions. Where there was one statement about a rendition, there was an identical statement about the other rendition. The subjects were required to tick one of the five rankings to indicate to what extent they agreed or disagreed with each statement. Following are the ten statements, each statement appearing twice in the questionnaire, one in relation to Cue Foreign and the other in relation to Cue Domestic. ${ }^{3}$

1. I feel as if I am in a foreign land when reading the extract.

2. I find it difficult to understand the extract.

3. The writer of the extract is imaginative.

4. The book extracted from is cultivated.

5. The book extracted from was published in a prosperous society.

6. I find the scene described in the extract unfamiliar. ${ }^{4}$

7. The extract doesn't make sense to me.

8. The writer of the extract has great literary expressions.

9. The book extracted from is a literary masterpiece.

10. The book extracted from was published in a civilized society.

The ten statements were designed to fit into five pre-constructed categories. Statements (1) and (6) addressed the potential of a rendition to empathically relocate a subject to a foreign country, with the former being a direct statement and the latter an indirect statement; (2) and (7) addressed the cognitive accessibility of a rendition; (3) and (8) addressed the literary quality of the ST author; (4) and (9) addressed the literary and cultural quality of the book extracted from; (5) and (10) addressed the social cultural environment of the book extracted from.

The questionnaire was designed to facilitate the testing of the hypotheses. The paired statements were intended to test hypothesis (1), i.e., that the two renditions would induce different perceptions from the subjects. Inclusion of statement (1) and (6) were intended to test hypothesis (2), i.e., that the foreignized rendition would give 
readers a greater feeling of being in a foreign environment when reading it. The categorization of the statements was intended to test hypothesis (3), i.e., that whether a cue prompted a feeling of being in a foreign environment would be correlated to other sociolinguistic perceptions about the cue.

\subsection{The interviews}

In the survey, the subjects were presented with the questionnaire beginning with the two cues, which were presented as Text A and Text B. Words like "foreign," "domestic" or "translation" might have served to frame responses and therefore did not appear on the questionnaire instructions. To maximize randomnicity, half of the questionnaires had Cue Foreign preceding Sample Domestic and the other half had Cue Domestic preceding Cue Foreign. The subjects were told that they could always revisit the cues to facilitate their responses to the statements about them. They were then asked to respond to each of the paired statements, one in relation to Cue Foreign and the other in relation to Cue Domestic to indicate the extent to which they agreed with each statement.

\section{Data analysis with regard to the hypotheses}

We subjected the survey data to statistical analyses and the result is presented in tables 1, 2 and 3. Table 1 addresses hypotheses (1) and (2) by comparing the responses to the two cues and indicating if there are any statistically significant differences between perceptions about the two. Tables 2 and 3 address hypothesis (3) by examining the correlativity between responses to Cue Domestic (Table 2) and between responses to Cue Foreign (Table 3 ) respectively, especially between responses to statements (1) and (6) and between either (1) or (6) and each of the other statements.

\subsection{Addressing hypothesis (1): Was the foreignized translation seen as different from the domesticated translation?}

On the whole, the processed data presented a case for rejecting rather than accepting hypothesis (1), namely there would be different perceptions about the two renditions. As can be seen from table 1 , of the 10 pairs of identical statements regarding the two cues, responses to 8 pairs had a significance (Sig.) value greater than 0.05 and therefore should be deemed statistically not distinguishable. Responses to only 2 pairs were significantly different. The two statements that caused different responses were (1) and (3) and responses to both of them were biased towards the "foreignized" rendition. That is, the subjects felt more as if they were in a foreign country when reading Cue Foreign than Cue Domestic and found the writer of Cue Foreign to be more imaginative than that of Cue Domestic. In principle, this result corroborated the findings of the Beijing and Guangzhou projects. But we will reserve the corroboration for an upcoming dedicated discussion.

Table 1 presents the data in detail by indicating in the two left columns the statement number and the cues and, in the other columns to the right, statistics of responses to each statement, i.e., number of valid responses $(\mathrm{N})$, means of response (Means), difference between responses in relation to the two renditions (Paired 
Differences), deviation of a value from the standard (Std Dev), T values (T) used for deciding whether to reject the null hypothesis and the significance level (Sig). We adopted Miller et al's "rule of thumb" for setting the level of significance (Sig.) at 0.05, which meant "that five times out of every 100 you would find a statistically significant difference even if there was none." (Miller et al. 2002: 118) In other words, we decided that any value of 0.05 or more was not acceptable for verifying the hypothesis.

TABLE 1

Comparative statistics of responses to the two cues

\begin{tabular}{|c|c|c|c|c|c|c|c|}
\hline State No & Cue & $\mathrm{N}$ & $\mathrm{M}$ & Paired D & Std. Dev & $\mathrm{T}$ & Sig. \\
\hline \multirow{2}{*}{$\begin{array}{l}1 . \\
2 .\end{array}$} & Domestic & \multirow[t]{2}{*}{72} & 2.4861 & \multirow[t]{2}{*}{-0.9444} & \multirow[t]{2}{*}{1.5645} & \multirow[t]{2}{*}{-5.122} & \multirow[t]{2}{*}{$\underline{0.000}$} \\
\hline & Foreign & & 3.4306 & & & & \\
\hline \multirow{2}{*}{$\begin{array}{l}3 . \\
4 .\end{array}$} & Domestic & \multirow[t]{2}{*}{71} & 2.4789 & \multirow{2}{*}{-0.2676} & \multirow[t]{2}{*}{1.6121} & \multirow[t]{2}{*}{-1.399} & \multirow[t]{2}{*}{0.166} \\
\hline & Foreign & & 2.7465 & & & & \\
\hline \multirow{2}{*}{$\begin{array}{l}5 . \\
6 .\end{array}$} & Domestic & \multirow[t]{2}{*}{72} & 3.0556 & \multirow[t]{2}{*}{-0.3611} & \multirow[t]{2}{*}{1.3871} & \multirow[t]{2}{*}{-2.209} & \multirow[t]{2}{*}{$\underline{0.030}$} \\
\hline & Foreign & & 3.4167 & & & & \\
\hline \multirow{2}{*}{$\begin{array}{l}7 . \\
8 .\end{array}$} & Domestic & \multirow[t]{2}{*}{72} & 3.2222 & \multirow[t]{2}{*}{0.2083} & \multirow[t]{2}{*}{1.3629} & \multirow[t]{2}{*}{1.297} & \multirow[t]{2}{*}{0.199} \\
\hline & Foreign & & 3.0139 & & & & \\
\hline \multirow{2}{*}{$\begin{array}{l}9 . \\
10 .\end{array}$} & Domestic & \multirow[t]{2}{*}{72} & 2.8333 & \multirow[t]{2}{*}{-0.2361} & \multirow[t]{2}{*}{1.2726} & \multirow[t]{2}{*}{-1.574} & \multirow[t]{2}{*}{0.120} \\
\hline & Foreign & & 3.0694 & & & & \\
\hline \multirow[t]{2}{*}{11.} & Domestic & \multirow[t]{2}{*}{72} & 2.8889 & \multirow[t]{2}{*}{0.0416} & \multirow[t]{2}{*}{1.1920} & \multirow[t]{2}{*}{0.297} & 0.768 \\
\hline & Foreign & & 2.8472 & & & & \\
\hline 12. & Domestic & 72 & 2.2500 & -0.0417 & 1.1681 & -0.303 & 0.763 \\
\hline 13. & Foreign & & 2.2917 & & & & \\
\hline 14. & Domestic & 72 & 3.2778 & -0.1111 & -0.678 & -0.678 & 0.500 \\
\hline 15. & Foreign & & 3.3889 & & & & \\
\hline 16. & Domestic & 72 & 3.1667 & -0.0416 & 1.2609 & 0.280 & 0.780 \\
\hline 17. & Foreign & & 3.1250 & & & & \\
\hline 18. & Domestic & 72 & 3.0139 & 0.1111 & 1.2952 & 0.728 & 0.429 \\
\hline & Foreign & & 2.9028 & & & & \\
\hline
\end{tabular}

Sig. $\leq 0.05$; i.e., values of 0.05 or more are not significant.

\subsection{Addressing hypothesis No 2: Did the foreignized translation prompt a greater feeling of being in a foreign environment than the domesticated translation?}

The processed data presented a case for both a positive and a negative answer to the above question. Responses to statement (1), namely, "I feel as if I am in a foreign land when reading the extract," were significantly distinguishable in response to the two cues, with the significance value being 0.00. With a bias against Cue Domestic in favour of Cue Foreign and with a paired difference between the two means being 0.9444, the statistics can be interpreted to the effect of saying that the subjects felt more as if they were in a foreign land when reading Cue Foreign than Cue Domestic. On the other hand, responses to statement (6), namely, "I find the scene described in the extract unfamiliar," were not at all significantly distinguishable in response to the two cues, with the significance value being 0.768 . In fact, there was a negligible bias towards Cue Domestic against Cue Foreign with a paired difference between the 
two means being 0.0416 . Furthermore, correlativity analysis, to be discussed next in the context of hypothesis (3), was to confirm that there was no significant correlation between responses to statements (1) and (6).

In earlier discussions of the research design and the questionnaire used by the present project, I explained that 陌生 /mosheng/, as found in statement (6), which had been literally translated into "unfamiliar" to facilitate discussion in this paper, means unfamiliar, strange, alien and outlandish in Chinese. The indistinguishable responses to the statement allowed only one interpretation, namely that neither of the two cues looked more familiar or unfamiliar than the other to the subjects. Now we face an interesting phenomenon, or even a paradox of some kind, from this Douliou project. The subjects agreed that Cue Foreign looked more foreign than Cue Domestic to the extent that they did feel as if they were in a foreign land when reading the former. But they also stated that the former one, although foreign looking, did not seem more unfamiliar to them.

\subsection{Addressing hypothesis (3): What did "the foreign" mean to the subjects?}

What did foreignness mean to the subjects? If a text made them feel as if they were in a foreign land, would they also think that the text was cognitively more difficult, literarily more sophisticated, culturally and socially more valued or otherwise? To answer these questions, we subjected the fieldwork data in relation to each cue to correlativity analyses.

In the correlativity analyses, we compared responses to statement (1) (containing explicit mention of a foreign country) with those to the other statements. We then compared responses to statement (6) (containing an allusion to foreignness) with those to the other statements. Values generated on the basis of statistical analyses in relation to Cue Domestic were entered into table 2. Values generated on the basis of statistical analysis in relation to Cue Foreign were entered into table 3. By doing so, we were able to see if there was a correlation between perceptions of "foreignness" and other sociolinguistic perceptions.

Before describing the data analysis, we would like to state the two conventions we adopted for determining validity and strength of a correlation. The first convention required the significance level (Sig.) of a correlativity value to be less than 0.05 for the value to be valid (Miller et al. 2002). By this convention, 4 of the 18 values in relation to Cue Domestic as presented in table 2, and 9 of the 18 values in relation to Cue Foreign as presented in table 3 were valid. These valid values are underlined in the tables. The second convention was about the strength of a correlative value. We adopted Black's scale of relative strength, according to which a correlative value should exceed +0.4 or -0.4 to show a moderate positive or reverse association and exceed +0.7 or -0.7 to show a strong association (Black 1993: 137). Where a correlativity value is more than moderate as well as significant, it is boldfaced and underlined in the tables. 
TABLE 2

Correlative values (Cor.) and significance value (Sig.) of responses to Cue Domestic

\begin{tabular}{|l|l|r|r|r|r|r|r|r|r|r|r|}
\hline Statements & & \multicolumn{1}{|c|}{1} & \multicolumn{1}{c|}{2} & \multicolumn{1}{c|}{3} & \multicolumn{1}{c|}{4} & \multicolumn{1}{c|}{5} & \multicolumn{1}{c|}{6} & \multicolumn{1}{c|}{7} & \multicolumn{1}{c|}{8} & \multicolumn{1}{c|}{9} & \multicolumn{1}{c|}{10} \\
\hline \multirow{2}{*}{1} & Cor & N/A & 0.073 & 0.101 & 0.110 & -0.063 & -0.214 & -0.036 & 0.153 & 0.059 & -0.084 \\
\cline { 2 - 12 } & Sig & N/A & 0.547 & 0.398 & 0.356 & 0.6 & 0.071 & 0.763 & 0.199 & 0.620 & 0.483 \\
\hline \multirow{2}{*}{6} & Cor & -0.214 & 0.252 & -0.105 & -0.232 & 0.076 & N/A & 0.213 & -0.247 & -0.054 & 0.242 \\
\cline { 2 - 11 } & Sig & 0.071 & $\underline{0.034}$ & 0.381 & $\underline{0.05}$ & 0.528 & N/A & 0.073 & $\underline{0.036}$ & 0.655 & $\underline{0.04}$ \\
\hline
\end{tabular}

An Underlined value indicates that the correlativity (Cor) value above it is significant (Sig. $\leq 0.05$; i.e., values of 0.05 [or -0.05 ] or more are not significant). Where a correlativity value is moderate or more as well as significant, it is boldfaced and underlined.

TABLE 3

Correlative values (Cor.) and significance value (Sig.) of responses to Cue Foreign

\begin{tabular}{|l|l|c|r|r|r|r|r|r|r|r|r|}
\hline Statements & & 1 & \multicolumn{1}{c|}{2} & \multicolumn{1}{c|}{3} & \multicolumn{1}{c|}{4} & \multicolumn{1}{c|}{5} & \multicolumn{1}{c|}{6} & \multicolumn{1}{c|}{7} & \multicolumn{1}{c|}{8} & \multicolumn{1}{c|}{9} & \multicolumn{1}{c|}{10} \\
\hline \multirow{2}{*}{1} & Cor & N/A & -0.210 & 0.248 & 0.262 & 0.083 & 0.093 & -0.124 & 0.026 & 0.242 & -0.063 \\
\cline { 2 - 11 } & Sig & N/A & 0.079 & $\underline{0.036}$ & $\underline{0.026}$ & 0.49 & 0.439 & 0.3 & 0.831 & $\underline{0.041}$ & 0.602 \\
\hline \multirow{2}{*}{6} & Cor & 0.093 & $\underline{0.448}$ & -0.282 & $\underline{-0.4}$ & -0.032 & N/A & 0.241 & $\underline{-0.416}$ & -0.192 & 0.357 \\
\cline { 2 - 10 } & Sig & 0.439 & $\underline{0.000}$ & $\underline{0.016}$ & $\underline{0.001}$ & 0.79 & N/A & $\underline{0.042}$ & $\underline{0.000}$ & 0.106 & $\underline{0.002}$ \\
\hline
\end{tabular}

An Underlined value indicates that the correlativity (Cor) value above it is significant (Sig. $\leq 0.05$; i.e., values of 0.05 [or -0.05 ] or more are not significant). Where a correlativity value is moderate or more as well as significant, it is boldfaced and underlined.

As is shown in tables 2 and 3 , in line with the two conventions, there was not a single valid strong correlation between responses to the statements in relation to either cue. There was not even a single valid moderate correlation between responses to the statements in relation to Cue Domestic, as is evident from table 2. With regard to Cue Foreign, there were merely three instances of significant moderate correlations between responses to the statements, as can be seen in table 3 . They included a positive one between responses to statements (6) and (2) and two reverse ones between responses to statements (6) and (4) and between responses to (6) and (8). The three moderate correlations can be stated as follows:

- A subject who "found the scene described in the text unfamiliar" had a moderate chance to also agree that he/she "had difficulty understanding the text"

- A subject who "found the scene described in the text unfamiliar" had a moderate chance to also disagree that "the book extracted from was cultivated," and

- A subject who "found the scene described in the text unfamiliar" had a moderate chance to also disagree that "the writer of the extract had great literary expressions."

In short, subject to the two conventions for establishing correlations, there were only 3 valid instances of moderate correlations against a total of 33 instances of invalid or negligible correlations. This ratio presented a case for rejecting rather than accepting hypothesis (3).

Of special interest to the researchers, no correlations were found between responses to statement (1) and those to any of the other statements in relation to either cue. This emphatically meant that a subject who "felt as if he/she was in a foreign country" when reading either cue did not necessarily "find the scene described in the 
extract unfamiliar." As importantly, a subject who "felt as if he/she was in a foreign country" did not necessarily "have difficulty understanding the text" or "find the text not making sense to him/her." Nor did that subject think predictably in relation to other sociolinguistic qualities of the extract, its author and the book extracted from. This again corroborates most of the findings of the Beijing and Guangzhou project in particular and warrants a dedicated discussion shortly.

\subsection{Addressing hypothesis (4): Are the Taiwan findings different?}

The processed data presented a stronger case for accepting than rejecting hypothesis (4), namely that the findings of the Taiwan project would corroborate the findings of the Beijing and Guangzhou projects. Yes, there were some minor variations, including notably the findings in relation to hypothesis (2). The foreignized translation prompted a greater feeling of being in a foreign land in this project as well as in the Guangzhou project but not in the Beijing project.

In most of the other aspects, considerable consistency was found across the findings of the three projects, including the following: the two cues were found to impact more indistinguishably than distinguishably on the subjects. Neither of the cues was found to be more unfamiliar even if, as in the case of Cue Foreign in the present project, it did prompt the subjects to feel as if they were relocated to a foreign land when reading it. Very few correlations were found between the foreignness of either cue and other sociolinguistic perceptions about the cues. Lastly there is one other consistent finding, which we are unable to explain on the basis of the available data. As in the precursors, we again found in this Taiwan project that the Cue Foreign was thought to have been the work of an imaginative writer.

\section{Significance of the project findings}

Having statistically processed and analysed the data of the Taiwan project, we will now discuss the meanings and implications which we would like to read into the evidence presented to us. Firstly, the "foreignized" and "domesticated" renditions looked indistinguishable in more heuristically constructed aspects to the subjects and distinguishable in fewer of these aspects. Where they did look distinguishable, the foreignized translation more than the domesticated translation prompted the subjects to feel as if they were in a foreign land when reading it. But interestingly, the former did not appear to be more unfamiliar than the latter.

Secondly, there was little significant correlation between a subject's perceptions in relation to either of the two renditions. Especially the absence of correlation between an idea of "being in a foreign land" and other sociolinguistic ideas was meaningful and will be discussed in detail in the next paragraph. Where there were correlations, they were moderate and were between an idea of "finding the scene unfamiliar" and other sociolinguistic ideas. Namely a subject who "found the scene described in Cue Foreign unfamiliar" also had a moderate chance to agree that he/she "had difficulty understanding the text" and to disagree that "the book extracted from was cultivated" or "the writer of the extract had great literary expressions." The first correlation seemed to be natural and logical to us because it is usually difficult for average people to understand things unfamiliar. The other two correlations may or 
may not have been significant and we do not have solid explanations except speculating that it would have been hard for anyone to form opinions about whether a description of an unfamiliar scene was extracted from a cultivated book or authored by a writer of great literary expressions.

Thirdly and very importantly to the project researchers, no correlations were found between a subject's feeling of relocation to a foreign country when reading either of the renditions and his/her other soicolinguistic ideas about the text. There was no correlation even between ideas of "relocation to a foreign country" or "finding the scene described in the text unfamiliar" or "having difficulty understanding the text" or whatever other sociolinguistic ideas about the text. As already noted, this absence of correlation had earlier been found in the Beijing and Guangzhou projects and hence the fortuity of the finding was minimal.

On the basis of the precursors, Zhong and his associates started conceptualising what they called "foreign familiar." This project contributed to reinforcing that conceptualization by finding that, while they might have difficulty understanding an "unfamiliar" text, the subjects did not necessarily have difficulty understanding a text which induced an idea of "relocation to a foreign country." Nor did they attach other sociolinguistic ideas to that text in a predictable or systematic manner.

Why was the "foreign familiar" such an important concept? The importance had to do with the assumptions underlying a range of more common thoughts in translation studies, including foreignization and domestication. Lu (1991), late writer and translator reputed to be the father of modern Chinese literature, advocated using the foreign accent to translate Western works into Chinese to reform and to revolutionise the familiar but archaic Chinese language and reality. Venuti (1995), who perceived fluent English translation of foreign texts as perpetuating the Anglo-Saxon cultural hegemony, advocated using translation as a political resistance project and using foreignized translation to send readers abroad and to dispel their cognitive comfort. Wen and Gao (2003), whose works facilitated our construction of the two cues (i.e., the renditions), also believed that foreignized translation was not readerfriendly. In his analysis of brand name translation into Chinese, Zhong (1999) himself echoed Venuti when he argued that transliteration, a method he identified as pro-foreignization, served the interest of the project of westernisation. Apparently, everyone cited above assumed that the foreign, as embodied by things foreign including foreign countries, foreign languages and foreign culture, were equal to the unfamiliar, the unknown, the alien, the strange and the outlandish.

But the findings of the Taiwan project as well as those of its precursors now suggests to us that the foreign may not be unfamiliar, alien, unknown, strange and outlandish. There is also that other possibility that a foreign-looking text may not induce predictable or consistent perceptions, including either positive or negative ones about the foreign-looking text. If the foreign is not unfamiliar or is not loaded with extra positive or negative sociolinguistic values, what is the point of foreignizing or domesticating a translation? In short, it is not unreasonable to suggest that, while they are valid heuristic and academic concepts, "foreignization" and "domestication," among others, may not align with the perception of real-life people living in a world that is increasingly globalised, diversified and fragmented.

With regard to our readers, their perceptions were found to be much more complex, inconsistent and fluid than we could academically categorize. They might agree 
that they did feel as if they were in a foreign land when reading the academically identified "foreignized" rendition and that the author of that text was imaginative. They might understandably think that an unfamiliar scene was difficult to understand, was not authored by a writer of great literary expression and was not extracted from a book of cultivation. On the whole, however, we had yet to find significantly consistent, predictable pattern or correlations between the many ideas they might have about translation. In other words, we failed to generate empirical evidence to justify either a wish or a fear for foreignized translation.

\section{Conclusion}

This paper discussed the findings of an impact study project completed in the Taiwanese city of Douliou. The project was the third of a trilogy and the previous two projects had been completed in the Chinese cities of Beijing and Guangzhou respectively. The purpose of this project was to test four hypotheses, namely that there would be distinct perceptions about two renditions, that the foreignized rendition would induce the subjects to feel as if they were in a foreign land, that there would be correlations between perceptions about either rendition and that the findings of the present project would corroborate those of the precursors.

The paper began with an introduction to the background and purposes of the project. The introduction was followed by a brief description of the research design and methodology, including especially how the sampled subjects were engaged to inspect two renditions, one being "foreignized" and another being "domesticated," of the same ST and to make responses to them, which were then statistically analysed. Then the paper presented the processed data and made interpretations of them. On the basis of the data analyses, we discussed the findings, which presented evidence for testing the hypotheses and for generating the following findings. In short, the two renditions were found to impact indistinguishably on the subjects. Neither cue (including especially Cue Foreign in the present project) was found to be more unfamiliar even if it did prompt the subjects to feel as if they were relocated to a foreign land when reading it. Very few correlations were found between the foreignness of either cue and other sociolinguistic perceptions about the cues. These findings were fairly consistent with those of the two previous projects.

Finally, we discussed the significance of the project findings. On the basis of the findings generated by the Taiwan project, we further elaborated on the concept of the "foreign familiar." We believe this to be an important concept because it facilitates academic reflections on such common popular concepts as "foreignization" and "domestication." Our conclusion is that, if the foreign is familiar rather than unfamiliar, the assumptions underlying these popular concepts may be suspect. That is to say, it is now time to reconceptualize the foreign, foreignization and the like and to start considering the possibilities of the familiar foreign or the foreign familiar (and, by analogy, the alien local and the unknown local) in translation studies. This last point, we believe, is the most significant contribution to knowledge enhancement made by this Taiwan project. 


\section{NOTES}

1. Separate papers have been authored on the basis of the Beijing and Guangzhou projects. The Beijing based paper is entitled "Lost between Foreignization and Domestication? A Translation Impact Study of a Group of Chinese University Students" and is being reviewed. The Gungzhou based paper is entitled "Are Readers Lost in Foreignland?" and is published by The Perspectives (Zhong and Lin 2007).

2. In their project, Lambert and his associates constructed two "guises" out of English and French utterances by the same speaker and hence the choice of spoken language (English or French) constituted the single variable. See Lambert (1967) for details of the original matched guise study by Wallace Lambert and his associates.

3. The original questionnaire used to survey the subjects was in Chinese language. The statements reprinted in this paper are literal English translations completed by the authors.

4. "Unfamiliar" is an English rendition, not an exclusive or precise equivalent, of the Chinese source word 陌生, pronounced 'mosheng,' used in the questionnaire. The lexicon means unfamiliar, strange, alien and outlandish in Chinese. We selected the rendition for presentation in this paper but would like our readers to be aware of the other meanings of the word.

\section{REFERENCES}

Benjamin, Walter (1963): Die Aufgabe des Übersetzers. In: Hans Joachim Störig, ed. Des Problem des Übersetzens. Darmstadt: Wissenschaftliche Buchgesellschaft.

Berman, Antoine (1985): La traduction comme épreuve de l'étranger. Texte. 4:67-81.

BLACK, Thomas R. (1993): Evaluating social science research. London: Sage Publications.

LAmbert, Wallace E. (1967): The social psychology of bilingualism. Journal of Social Issues. 23:91-109.

Lu, Xun (1991): Nalai zhuyi (Grab-ism). In: Lu Xun Quanji (Comprehensive Work Collection by Lu Xun). Beijing: People's Literature Publishing House, 38-41.

Miller, Robert L., Acton, Ciaran, Fullerton, Deirdre and Maltby, John (2002): SPSS for social scientists. London: Palgrave Macmillan.

SChleiermacher, Friedrich (1813/1992): Über die verschiedenen methoden des übersetzens (On the different methods of translating). In: Rainer Schulte and John Biguenet, eds. Theories of translation: an anthology of essays from Dryden to Derrida. Chiacago: University of Chicago Press, 36-54.

Venuti, Lawrence (1995): The translator's invisibility: a history of translation, London: Routledge.

WEN, Jun and GAO, Xiaoying (2003): A functionalist critique of two Chinese translations of Gone with the Wind. Chinese translators journal. 24(5):40-43.

ZHoNG, Yong (1999): To transliterate or not to transliterate, that is the question of national identity. Journal of Translation Studies. 3:81-96.

Zhong, Yong and Lin, Jie (2007): Are Readers Lost in the Foreign Land? Investigating the Impact of Foreignized Translation in Guangzhou. Perspectives: Studies in Translatology. 15(1):1-14.

\section{APPENDIX}

English ST extracted from Gone with the Wind by Margaret Mitchell in 1936, which is the basis of the two cues.

This Ashley Wilkes in his faded, patched uniform, his blond hair leached tow by summer suns, was a different man from the easy-going, drowsy-eyed boy she had loved to desperation before the war. And he was a thousand times more thrilling. He was bronzed and lean now, where he had once been fair and slender, and the long golden moustache drooping about his mouth, cavalry style, was the last touch needed to make him the perfect picture of a soldier. 
356 MetA, LIV, 2, 2009

\section{Cue Domesticated}

他回家时, 身上穿着退色补辍的军服, 头发已被烈日灼晒成了漂过的麻屑一般, 跟战前 她所痴迷的那个潇酒风流的男子完全不同了。从前他是风度翩翩的, 现在他变成了红 铜色了, 瘦了。两僘金黄色的长髭须挂在口角, 竟是一个道地的兵大爷了。

\section{Cue Foreign}

眼前的他穿着打了补丁、裉了色的军服, 满头金发被太阳晒得像是裉了色的短亚麻, 跟 战前她苦恋过的那个从容不迫、目光困倦的男孩子判若两人。然而他却一千倍地令她 心神荡漾。从前的他, 皮肤白晳, 身材修长匀称, 现在皮肤变成了古铜色, 人又瘦。加 上金黄的长髡像骑兵惯常留的那样, 挂在嘴巴四周, 这就使他看起来像个道道地地的 大兵了。 